\title{
Geriatric traumas in the judicial reports of Adana, Turkey
}

\begin{abstract}
Geriatric trauma have importance in preventive medicine because of they can be prevented. So we evaluated geriatric cases which have judicial reports and we performed demographic distributions and presented lesion severities in our study. One hundred twenty-one cases which had applied to Çukurova University Forensic Medicine Department over the age of 65 were evaluated retrospectively. 90 cases (74.3\%) were in early elderly group, 29 cases $(24 \%)$ were in middle aged elderly group. 72 cases $(59.5 \%)$ were male. 112 cases $(92.5 \%)$ were sent by police departments, 6 cases $(5 \%)$ were sent by gendarmerie stations and 3 cases $(2.5 \%)$ were sent by prosecution office/court in order to prepare judicial reports by us. 69 cases $(57 \%)$ had experienced blunt trauma, 40 cases $(33 \%)$ had experienced traffic accident, 5 cases $(4.2 \%)$ had experienced penetrating object traumas, 2 cases $(1.6 \%)$ had experienced wounding by firearms, 5 cases $(4.2 \%)$ were injured by other causes. 45 cases $(37.2 \%)$ had lesions at head - neck region, 36 cases $(29.8 \%)$ had lesions at extremities, 4 cases $(3.3 \%)$ had lesion on thorax, 4 cases $(3.3 \%)$ had lesion on abdomen, and 3 cases $(2.4 \%)$ had vertebra injuries. In 24 cases $(19.8 \%)$ there were legions both at head neck region and extremities and in 5 cases (4.2\%) there were multiple other injuries. Injuries in 25 cases $(20.6 \%)$ couldn't be cured by simple medical intervention, injuries in 8 cases $(6.6 \%)$ were life threatening, injuries in 6 cases $(4.9 \%)$ caused permanent scar in face, trauma in 21 cases $(17.3 \%)$ caused at least one bone fraction and injuries in 8 cases $(6.6 \%)$ was severe enough to cause function loss. Geriatric trauma cases are different mostly from the other age group trauma cases. Its predisposing factors can be prevented mostly.
\end{abstract}

Keywords: geriatric, trauma, report
Volume 6 Issue 3 - 2018

\author{
Kenan Kaya,' Mete Korkut Gülmen, ${ }^{2}$ Eren \\ Akgündüz,' Ebubekir Burak Çelik,' Ahmet \\ Hilal ${ }^{2}$ \\ 'Council of Forensic Medicine, Turkey \\ ${ }^{2}$ Department of Forensic Medicine, Cukurova University School \\ of Medicine, Turkey
}

Correspondence: Kenan Kaya, Ministry of Justice, Council of Forensic Medicine, Adana, Turkey, Tel +905066472403, Email k_kaya_7l@hotmail.com

Received: May 25, 2018 | Published: June 04, 2018

\section{Introduction}

Senility is a process which must be evaluated with the dimensions of physical, psychological and social. Most studies about senility discuss physiological dimension at senility definition and classification. Senility in physiological dimension represents changes seen with chronological ages; chronologic senility is defined as being over age 65 . Gerontologists classify senility as early senility period between ages of 65-74; middle senility period between ages of 75-84 and late senility period over the age of $85 .^{1-3}$ Elderly population is increasing in our country as well as at worldwide. At the year of 1985, people over the age of 65 forms $4.2 \%$ of Turkish population. This ratio is now $7.4 \%$ according to 2012 data. This ratio is expected to be as $12 \%$ at the year of $2020 .{ }^{4}$ Geriatric trauma cases is increasing everyday because of increased time of life and increased ratio of elderly people due to improved lifestyle conditions. For this reason this subject is being of more interest to forensic sciences. Despite the fact that trauma is considered as a situation specific to young population; it has the 5th place at leading causes of deaths among the people over 65 years in western societies. ${ }^{5}$

Trauma is a severe morbidity and mortality cause at elderly people. It is known that elderly people have more increased mortality, time of hospital stay and complications than young people who have similar injury. ${ }^{6}$ Patients who over the age of 65 constitute the important part of trauma cases. And this ratio is expected to rise severely in next decades. $25-28 \%$ of deaths associated with trauma are seen at the people over the age of 65 . Trauma is one of the leading causes of death among the people over the age of $65 . .^{7}$ Its 4 th frequent cause of death among all age groups following cardiac diseases, malignancy and stroke. ${ }^{1}$ Geriatric trauma have importance in preventive medicine because of they can be prevented. So we evaluated geriatric cases which have judicial reports and we performed demographic distributions and presented lesion severities in our study.

\section{Materials and method}

One hundred twenty-one cases which had applied to Çukurova University Forensic Medicine Department over the age of 65 were evaluated retrospectively. Cases were assessed in terms of age, gender, facility which demanded the report, event type, lesion area and content of the report.

\section{Findings}

One hundred twenty-one cases which had applied to Çukurova University Forensic Medicine Department over the age of 65; were classified to groups as early elderly period between the ages of 65-74, as middle aged elderly period between the ages of 75-84 and as late elderly period over the age of 85 . It was seen that; 90 cases $(74.3 \%)$ were in early elderly group, 29 cases $(24 \%)$ were in middle aged elderly group and 2 cases $(1.7 \%$ ) were in late elderly group (Figure 1). The ages of cases varied between 65 and 88 . When we look at the sex distribution it was seen that 72 cases $(59.5 \%)$ were male and 49 cases $(40.5 \%)$ were female (Figure 2). It draws attention that female elderly population is much higher than male elderly population but 
still number of male cases in traumatic events is higher. When we evaluate the facilities which demanded the reports, we saw that 112 cases $(92.5 \%)$ were sent by police departments, 6 cases $(5 \%)$ were sent by gendarmerie stations and 3 cases $(2.5 \%)$ were sent by prosecution office/court in order to prepare judicial reports by us.

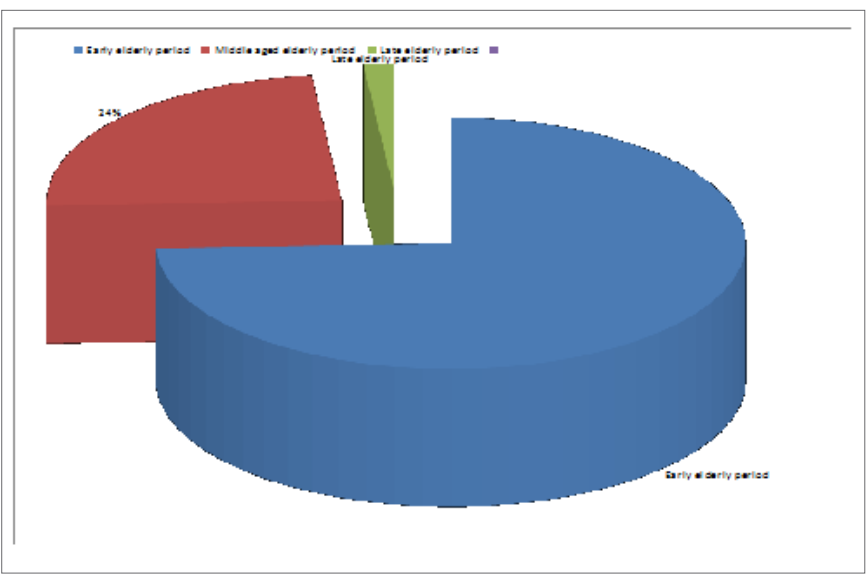

Figure I Geriatric age distrubition.

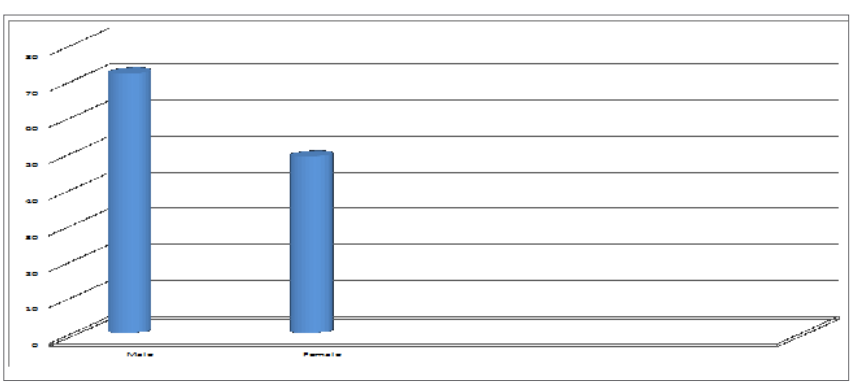

Figure 2 Geriatric sex distrubition.

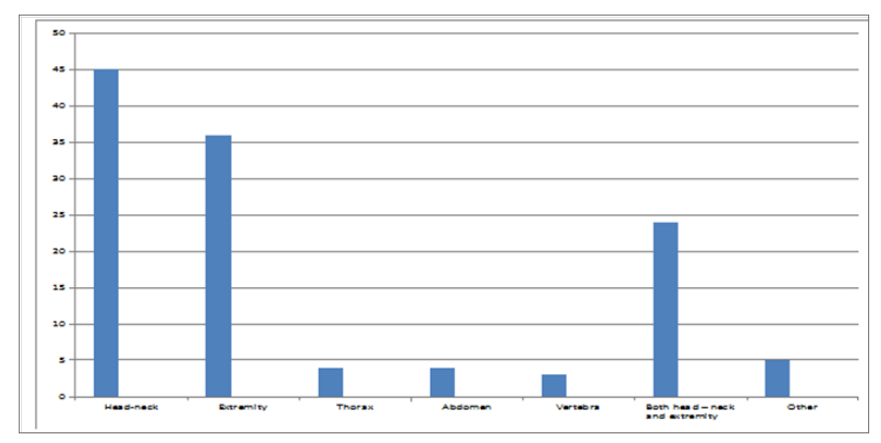

Figure 3 Distribution of cases according to the lesion site.

When we split the cases in groups for event types we saw that; 69 cases $(57 \%)$ were experienced blunt trauma, 40 cases $(33 \%)$ were experienced traffic accident, 5 cases $(4.2 \%)$ were experienced penetrating object traumas, 2 cases $(1.6 \%)$ were experienced wounding by firearms, 5 cases $(4.2 \%)$ were injured by other causes. When we evaluate the cases by lesion locations; we saw that 45 cases $(37.2 \%)$ had lesions at head - neck region, 36 cases $(29.8 \%)$ had lesions at extremities, 4 cases $(3.3 \%)$ had lesion on thorax, 4 cases $(3.3 \%)$ had lesion on abdomen, and 3 cases $(2.4 \%)$ had vertebra injuries. In 24 cases $(19.8 \%)$ there were legions both at head - neck region and extremities and in 5 cases (4.2\%) there were multiple other injuries (Figure 3). When we had analyzed the reports we saw that injuries in 25 cases $(20.6 \%)$ couldn't be cured by simple medical intervention, injuries in 8 cases $(6.6 \%)$ were life threatening, injuries in 6 cases $(4.9 \%)$ caused permanent scar in face, trauma in 21 cases $(17.3 \%)$ caused at least one bone fraction and injuries in 8 cases $(6.6 \%)$ was severe enough to cause function loss.

\section{Discussion}

Age and gender distribution at previous studies which are about geriatric population are found compatible with our study's distributions. Although female ratio is higher in geriatric population, female trauma cases ratio have been found lower in our study and previous studies contrary to expected. ${ }^{89}$ This situation can be explained for our country by the reasons like male population have more socialized lifestyle, males spend more time at traffic and they work more actively at the jobs which requires workforce. In a study which constitutes from geriatric trauma cases that applied to emergency department, average age was found as 71.5. In another study male average age was found as 73.8 and female average age was found as 74.2. ${ }^{10,11}$ That shows us geriatric trauma cases which apply to emergency department and require judicial report are formed mostly by the people at the early elderly group. When the facilities are analyzed which send the cases, police department domination draws attention. But its cause is thought as correspondences between court and prosecution office mostly occur via police department in our city. In a study which is about trauma cases over the age of 65 ; most seen trauma was defined as traffic accident (45\%). ${ }^{12}$ In another study which was performed in our country found that the second most common trauma type is blunt. ${ }^{13}$ In our study blunt trauma was found on the first place (57\%) and traffic accidents were found on the second place (33\%). This different result's causes might be people who experienced blunt trauma, usually don't apply to hospital but they are mandatory to come us for judicial report and although traffic accidents are more frequent they usually don't recorded as judicial event at hospitals.

Besides that decreased hearing and visual function with the increased age causes more frequent traffic accidents. In our study it is seen that most injured parts after geriatric traumas are head-neck $(37.2 \%)$ and extremities (29.8\%) respectively. This distribution mostly caused by the high frequency of blunt trauma in our study. The study which is performed by Kandiş et al., ${ }^{13}$ found that soft tissue trauma ratio is $49.1 \%$ and extremity trauma ratio is $16.1 \%$. (14) It was again caused by higher traffic accident frequency and traffic accidents mostly cause extremity and soft tissue injuries. But blunt traumas mostly cause head-neck and extremity injuries. When we had analyzed the reports we saw that injuries in 25 cases (20.6\%) couldn't be cured by simple medical intervention, injuries in 8 cases $(6.6 \%)$ were life threatening, injuries in 6 cases $(4.9 \%)$ caused permanent scar in face, trauma in 21 cases $(17.3 \%)$ caused at least one bone fraction and injuries in 8 cases $(6.6 \%)$ was severe enough to cause function loss. Its most important reason is high frequency of blunt traumas in our study. But when evaluated separately it is seen that traffic accidents cause the situations above more frequently. Blunt traumas tend to cause less severe injuries so it is also related with that result.

\section{Conclusion}

Geriatric trauma cases are different mostly from the other age group trauma cases. Its predisposing factors can be prevented mostly. So in our study we demonstrated demographic data of these trauma cases and injury severities according to that data. Precautions which are needed to prevent these cases are extremely important in terms of preventive medicine. Besides that much more elevated blunt trauma 
ratio in our study than hospital records shows that violence is much more frequent than expected and it is much more important problem than traffic accidents, so we have to make an effort to prevent violence and its consequences.

\section{Acknowledgements}

None.

\section{Conflict of interest}

Author declares that there is no conflict of interest.

\section{References}

1. Birren JE. The Psycology of Aging, Prentice Hall. Inc. New Jersey; 1982.

2. Psychogeriatric, report of a WHO Scientific Group, Technical Reports Series 507, Geneva. Epidemiology. 1972;14(1):9-21.

3. The uses of epidemiology in the study of the elderly. WHO, Technical Reports Series 706, Geneva: 1974;8-9.

4. Adrese dayalı nüfus kayıt sistemi 2012 y1lı sonuçlarl. T.C. Başbakanlık Türkiye İstatistik Kurumu Haber Bülteni. 2012.
5. Accident Facts: 1991 edn. Chicago, III: Nationel Safety Council; 1991.

6. Schwab CW, Kauder DR. Trauvma in the geriatric patients. Arch Surg 1992;127(6):701-6.

7. Akköse Aydin S, Bulut M, Fedakar R, et al. Trauma in the elderly patients in Bursa. Ulus Travma Acil Cerrahi Derg. 2006;12(3):230-4.

8. İkizceli İ, Sözüer EM, Bedirli A. Multitravmalı hastaların prognozunu belirlemede yaş faktörü. Ulus Travma Acil Cerrahi Dergisi. 1999;5(1):402 .

9. Bilgin NG, Mert E. Geriatrik yaş grubu adli olguların özellikleri. The Journal of Geriatrics. 2005;8(1):13-6.

10. Özdoğan M, Agalar F, Daphan CE, et al. Geriatrik travmada mortalite ve morbiditeye etki eden faktörler. Turkish Journal of Trauma\&Emergency Surg. 1999;5(3):189-193.

11. Tanrıkulu CŞ, Tanrıkulu Y. Geriatrik Popülasyonda travma analizi: Kesitsel Çalıșma. Yeni Tıp Dergisi. 2013;30(2):100-104.

12. Binder S. İnjuries among older adults: the challenge of optimizing safety and minimizing unintended conseguences. Inj Prev. 2002;8(Suppl) 4:2-4.

13. Kandiş H, Karakuş A, Katıreı Y, et al. Geriatrik yaş grubu ve adli travmalar. Turkish Journal of Geriatrics. 2011;14(3):93-8. 